\title{
PHYLOGENETIC RELATIONSHIPS OF BRACENICA RADOMAN, 1973 (CAENOGASTROPODA: TRUNCATELLOIDEA)
}

\author{
SEBASTIAN HOFMAN ${ }^{1 *}$, JOZEF GREGO ${ }^{2}$, ALEKSANDRA RYSIEWSKA ${ }^{3}$, ARTUR OSIKOWSKI ${ }^{4}$, \\ ANDRZEJ FALNIOWSKI ${ }^{3}$, ZOLTÁN PÉTER ERŐSS ${ }^{5}$, ZOLTÁN FEHÉR ${ }^{5}$
}

\begin{abstract}
${ }^{1}$ Department of Comparative Anatomy, Institute of Zoology and Biomedical Research, Jagiellonian University, Gronostajowa 9, 30-387 Cracow, Poland (e-mail: s.hofman@uj.edu.pl); (1) https://orcid.org/0000-0001-6044-3055

${ }^{2}$ Horná Mičiná, Horná Mičiná, SK-97401 Banská Bystrica, Slovakia (e-mail: jozef.grego@gmail.com) ${ }^{3}$ Department of Malacology, Institute of Zoology and Biomedical Research, Jagiellonian University, Gronostajowa 9, 30-387 Cracow, Poland (e-mail: rysiewska.a@gmail.com, andrzej.falniowski@uj.edu.pl); AR (1) https://orcid.org/0000-0002-9395-9696, AF i https://orcid.org/0000-0002-3899-6857 ${ }^{4}$ Department of Animal Reproduction, Anatomy and Genomics, University of Agriculture in Krakow, Al. Mickiewicza 24/28, 30-059 Cracow, Poland (e-mail: artur.osikowski@urk.edu.pl); (1) https://orcid.org/0000-0001-6646-2687

${ }^{5}$ Department of Zoology, Hungarian Natural History Museum, Baross utca 13, H-1083 Budapest, Hungary (e-mail: erosspeter@hotmail.com, feher.zoltan@nhmus.hu); ZF 이 https://orcid.org/0000-0002-4888-1156

*corresponding author
\end{abstract}

\begin{abstract}
Shells of the representatives of the genus Bracenica Radoman, 1973: B. spiridoni, B. vitojaensis and a new species, collected at the Kotor Bay (Montenegro) are presented. For the new species also the operculum (characteristic of the genus), penis and the female reproductive organs are described and figured. Considering the shell, operculum, and soft part morphology the new species belongs to the genus Bracenica. Cytochrome oxidase subunit I (COI) of mitochondrial DNA sequence of the new species places it in the subfamily Sadlerianinae Szarowska, 2006, and Bracenica is the sister genus of Sadleriana Clessin, 1890. COI sequences of Hauffenia plana Bole, 1961 clearly indicate its placement within the genus Bracenica.
\end{abstract}

KEY WORDS: stygobiont, operculum, anatomy, mtDNA, COI, Hydrobiidae, Montenegro, Kotor Bay

\section{INTRODUCTION}

Bracenica spiridoni Radoman, 1973 is a freshwater species of valvatoid-shelled truncatelloid, recorded from the subterranean habitats and springs. It is endemic to Montenegro, its known distribution is restricted to only two localities in the Lake Skadar area: Spirov Izvor (a small spring ca. $2 \times 2 \mathrm{~m}$ ) and to Karuč spring (a sublacustrine spring: RADOMAN 1983). GLÖER et al. (2015) described another species of Bracenica: B. vitojaensis Glöer, Grego, Erőss et Fehér, 2015, from Vitoja Spring, Podgorica municipality, also close to Lake Skadar (Fig. 1). These descriptions were based on the shell morphology alone. However, it was demonstrated that shell morphology was often not sufficient for species delimitation in Hydrobiidae (e.g. OsIKOWSKI et al. 2015, RYSIEWSKA et al. 2016). Moreover, members of the genus Kerkia Radoman, 1978 with very similar shell morphology are known from a closely situated area - southern Bosnia and probabaly northern Montenegro. We found members of the genus Bracenica at a locality on the Kotor Bay, which extends its distribution range about 30 $\mathrm{km}$ northward. At another locality in the region we collected specimens of Hauffenia plana Bole, 1961 (BOLE 1961). The aim of this paper is to compare the 


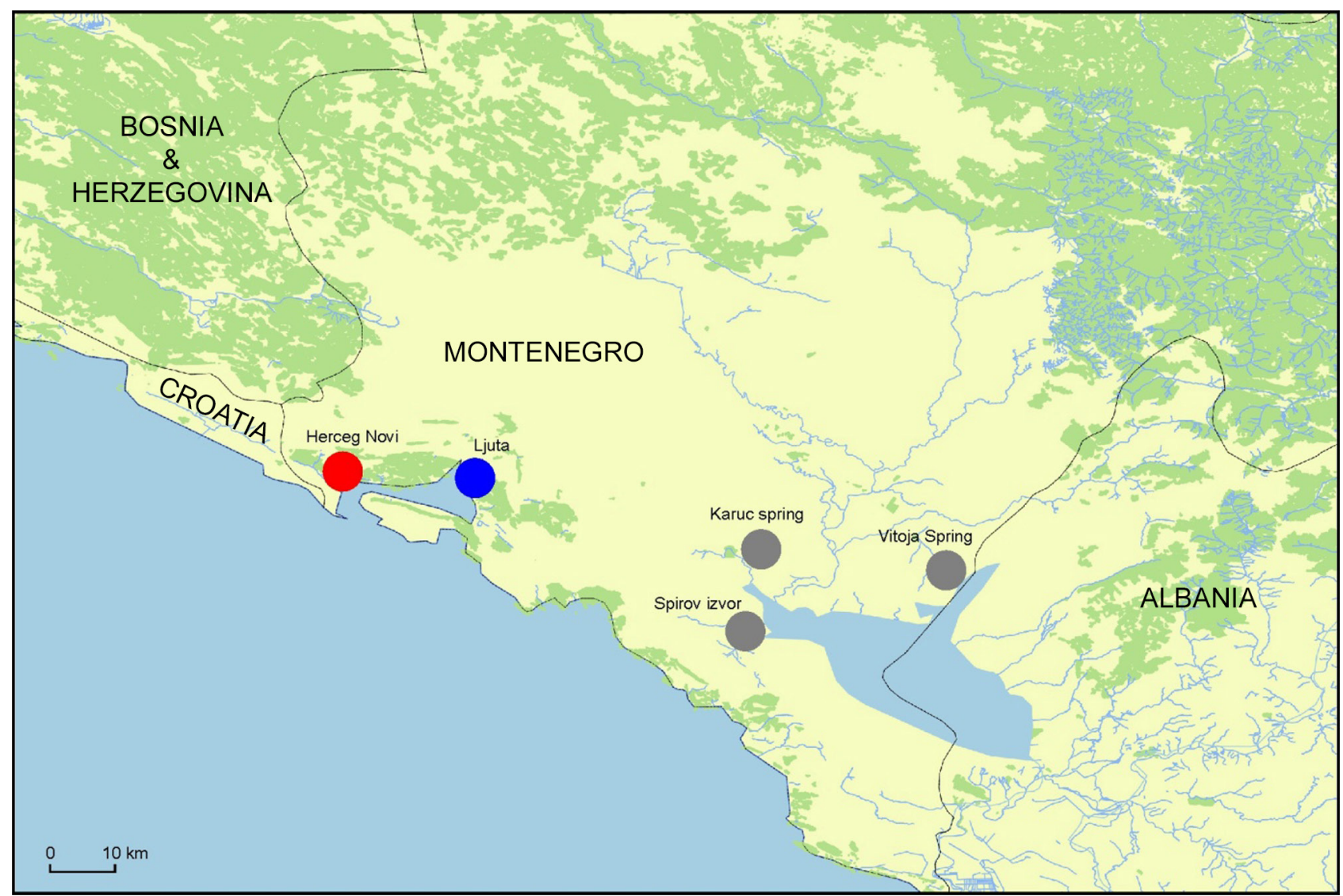

Fig. 1. Map with the type locality of Bracenica gloeri n. sp. (red dot), locality of Bracenica plana (Bole, 1961) (blue dot) and localities of other representatives of the genus (grey dots)

operculum and soft part morphology of our Bracenica with the other species of Bracenica, as well as to apply partial mitochondrial cytochrome oxidase subunit I
(COI) DNA sequence data to infer phylogenetic relationships of the newly found Bracenica, as well as of Hauffenia plana.

\section{MATERIAL AND METHODS}

Live individuals of Bracenica were collected at two localities on the Kotor Bay, Montenegro:

1. Spring behind the car wash Nickević at crossing of E65 and Bratsva Jedistva Street, Herceg Novi, Montenegro ( $42^{\circ} 27.72^{\prime} \mathrm{N}, 18^{\circ} 31.21^{\prime} \mathrm{E}$ ) (Fig. 1). A small spring, in the sand sediment and in dense web of roots hanging inside the spring water outlet (Figs 2-3);

2. Spring Ljuta between Orahovac and Dobrota, 7 $\mathrm{km} \mathrm{N}$ of Kotor $\left(42^{\circ} 29.13^{\prime} \mathrm{N}, 18^{\circ} 45.98^{\prime} \mathrm{E}\right)$.

The shells were sorted under binocular microscope OLYMPUS SZ-11 and the live specimens fixed in $80 \%$ analytically pure ethanol. The shells were photographed with a CANON EOS 50D digital camera attached to NIKON SMZ-18 stereoscopic microscope with the dark field. The operculum was cleaned in ultrasonic cleaner and examined using a HITACHI S-4700 scanning electron microscope, applying the techniques described by FALNIOWSKI
(1990). The dissections of the soft parts were done with NIKON SMZ-18 stereoscopic microscope with the dark field. Morphological characters' terminology follows HERSHLER \& PONDER (1998).

For DNA extraction, whole specimens with cracked shells were used. The tissue was hydrated in TE buffer $(3 \times 10 \mathrm{~min}$.$) ; then total genomic DNA$ was extracted with the SHERLOCK extracting kit (A\&A Biotechnology), and the final product was dissolved in $20 \mu \mathrm{l}$ of TE buffer. The extracted DNA was stored at $-80{ }^{\circ} \mathrm{C}$ at the Department of Malacology, Institute of Zoology and Biomedical Research, Jagiellonian University in Kraków (Poland). A fragment of the mitochondrial cytochrome oxidase subunit I (COI) was sequenced. Details of PCR conditions, primers used and sequencing were given in SZAROWSKA et al. (2016). Sequences were initially aligned in the MUSCLE (EDGAR 2004) programme in MEGA 6 (TAMURA et al. 2013) and then checked 
in BIOEDIT 7.1.3.0 (HALL 1999). Uncorrected p-distances were calculated in MEGA 6. The saturation test (XIA 2000, XIA et al. 2003) was performed using DAMBE (XIA 2013). In the phylogenetic analysis additional sequences from GenBank were used (Table 1). The data were analysed using approaches based on Bayesian inference (BI) and maximum likelihood (ML). We applied the GTR $+\Gamma$ model, as the main general whose certain parameters set either to 1 or 0 , respectively, presented all the other stationary models of DNA evolution. The parameters of the model were estimated by the RaxML (STAMATAKIS 2014). The BI was run using MrBayes v. 3.2.3 (RONQUIST et al. 2012) with the default

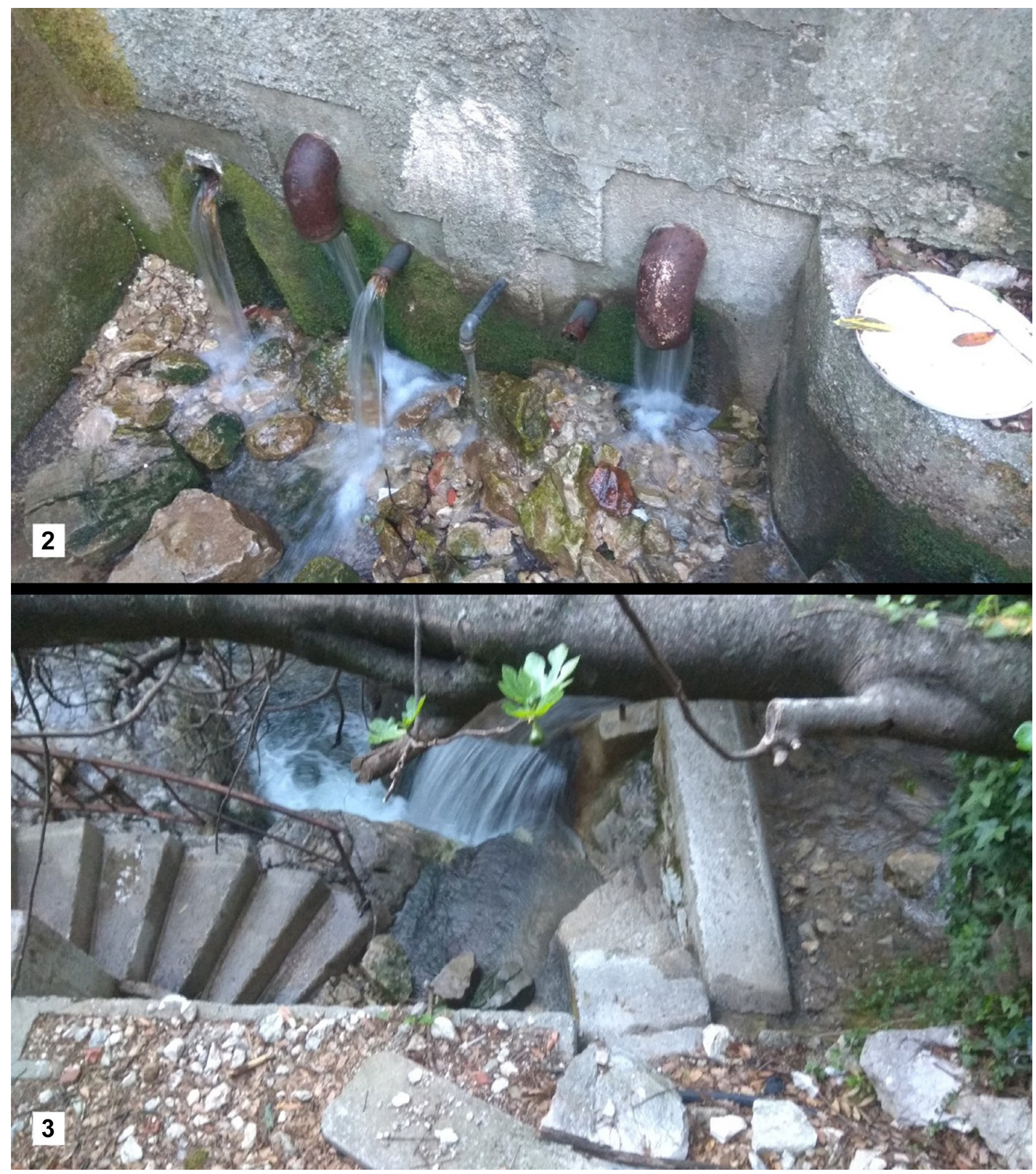

Figs 2-3. Type locality of Bracenica gloeri n. sp.: 2 - water outlet; 3 - rivulet from spring during the maximum water outlet during spring (Photo: Z. P. ERŐss) 
priors. Two simultaneous analyses were performed, each lasting 10,000,000 generations with one cold chain and three heated chains, starting from random trees and sampling trees every 1,000 generations. The first $25 \%$ of trees were discarded as burn-in. The analyses were summarized on a $50 \%$ majority-rule tree. Convergence was checked in Tracer v. 1.5 (RAMBAUT \& DRUMMOND 2009). FigTree v. 1.4.4 (RAMBAUT 2010) was used to visualise the trees. The ML approach was applied with RAxML v. 8.0.24 (STAMATAKIS 2014). RAxML analyses were performed using the free computational resource CIPRES Science Gateway (MILLER et al. 2010).
Abbreviations: AMNH - American Museum of Natural History, New York, USA; HNHM Hungarian Natural History Museum, Budapest, Hungary; NHMUK - Natural History Museum London, UK; NHMW - Naturhistorisches Museum Wien, Austria; NMBE - Naturhistorisches Museum, Bern, Switzerland; SMF - Senckenberg Museum, Frankfurt, Germany; AH - aperture height; AW - aperture width; $\mathrm{BH}$ - height of the body whorl; BW width of the body whorl; $\mathrm{H}$ - shell height; $\mathrm{W}$ - shell width; LT - locus typicus.

Table 1. Taxa used for phylogenetic analyses with their GenBank accession numbers and references

\begin{tabular}{|c|c|c|}
\hline Species & $\begin{array}{c}\text { COI } \\
\text { GB numbers }\end{array}$ & References \\
\hline Agrafia wiktori Szarowska et Falniowski, 2011 & JF906762 & SZAROWSKA \& FALNIOWSKI 2011 \\
\hline Alzoniella finalina Giusti et Bodon, 1984 & AF367650 & WILKE et al. 2001 \\
\hline Anagastina zetavalis (Radoman, 1973) & EF070616 & SZAROWSKA 2006 \\
\hline Avenionia brevis berenguieri (Draparnaud, 1805) & AF367638 & WILKE et al. 2001 \\
\hline Belgrandiella kusceri (Wagner, 1914) & KT218511 & FALNIOWSKI \& BERAN 2015 \\
\hline Bithynia tentaculata (Linnaeus, 1758) & AF367643 & WILKE et al. 2001 \\
\hline Bythinella austriaca (von Frauenfeld, 1857) & JQ639858 & FALNIOWSKI et al. 2012b \\
\hline Bythinella micherdzinskii Falniowski, 1980 & JQ639854 & FALNIOWSKI et al. 2012b \\
\hline Bythiospeum acicula (Hartmann, 1821) & KU341350 & RICHLING et al. 2016 \\
\hline Dalmatinella fluviatilis Radoman, 1973 & KC344541 & FALNIOWSKI \& SZAROWSKA 2013 \\
\hline Daphniola louisi Falniowski et Szarowska, 2000 & KM887915 & SZAROWSKA et al. 2014 \\
\hline Ecrobia maritima (Milaschewitsch, 1916) & KJ406200 & SZAROWSKA \& FALNIOWSKI 2014b \\
\hline Emmericia expansilabris Bourguignat, 1880 & KC810060 & SZAROWSKA \& FALNIOWSKI 2013a \\
\hline Fissuria boui Boeters, 1981 & AF367654 & WILKE et al. 2001 \\
\hline Graecoarganiella parnassiana Falniowski et Szarowska, 2011 & JN202352 & FALNIOWSKI \& SZAROWSKA 2011 \\
\hline Graziana alpestris (Frauenfeld, 1863) & AF367641 & WILKE et al. 2001 \\
\hline Grossuana codreanui (Grossu, 1946) & EF061919 & SZAROWSKA et al. 2007 \\
\hline Hauffenia tellinii (Pollonera, 1898) & KY087861 & RYSIEWSKA et al. 2017 \\
\hline Hauffenia michleri Kuščer, 1932 & KY087865 & RYSIEWSKA et al. 2017 \\
\hline Heleobia dobrogica (Grossu et Negrea, 1989) & EU938131 & FALNIOWSKI et al. 2008 \\
\hline Horatia klecakiana Bourguignat 1887 & KJ159128 & SZAROWSKA \& FALNIOWSKI 2014a \\
\hline Hydrobia acuta (Draparnaud, 1805) & AF278808 & WILKE et al. 2000 \\
\hline Iglica cf. gracilis (Clessin, 1882) & MH720985 & HOFMAN et al. 2018 \\
\hline Islamia zermanica (Radoman, 1973) & KU662362 & BERAN et al. 2016 \\
\hline Kerkia jadertina (Kuščer, 1933) & KY087874 & RYSIEWSKA et al. 2017 \\
\hline Lithoglyphus prasinus (Küster, 1852) & JX073651 & FALNIOWSKI \& SZAROWSKA 2012 \\
\hline Littorina littorea (Linnaeus, 1758) & KF644330 & LAYTON et al. 2014 \\
\hline Marstoniopsis insubrica (Küster, 1853) & AF322408 & FALNIOWSKI \& WILKE 2001 \\
\hline Moitessieria cf. puteana Coutagne, 1883 & AF367635 & WILKE et al. 2001 \\
\hline Montenegrospeum bogici (Pešić et Glöer, 2012) & KM875510 & FALNIOWSKI et al. 2014 \\
\hline Paladilhiopsis grobbeni Kuščer, 1928 & MH720991 & HOFMAN et al. 2018 \\
\hline Pontobelgrandiella sp. Radoman, 1978 & KU497024 & RYSIEWSKA et al. 2016/GREGO et al. 2017 \\
\hline Radomaniola curta (Küster, 1853) & KC011814 & FALNIOWSKI et al. 2012a \\
\hline Sadleriana fluminensis (Küster, 1853) & KF193067 & SZAROWSKA \& FALNIOWSKI 2013b \\
\hline Tanousia zrmanjae (Brusina, 1866) & KU041812 & BERAN et al. 2015 \\
\hline
\end{tabular}




\section{RESULTS}

\section{MOLECULAR PART}

We obtained 3 new sequences of COI (382 bp, GenBank Accession numbers MT396209MT396211). The tests of XIA et al. (2003) revealed little saturation. Results from the substitution saturation analysis showed an ISS $=0.75$, significantly smaller than the critical ISS value (0.95), indicating that all the sequences are useful in phylogenetic reconstruction. The topologies of the resulting phylograms were identical in both the maximum likelihood (ML) and Bayesian inference (BI). The three new sequences (two of the new species of Bracenica and one of Hauffenia plana) formed a distinct clade, closely related to Sadleriana fluminensis (Fig. 4).

The inferred tree reflects a common problem saturation results in low resolution of deep nodes, showing one big polytomy, if only COI is applied. Unfortunately, our snails were not well fixed, thus it was possible to get only short sequences of COI. This was still enough to confirm that Bracenica gloeri and $B$. plana are congeners, and they are closely related with Sadleriana and Horatia, as well as to reject closer relationships of Bracenica with the other genera included in the tree.

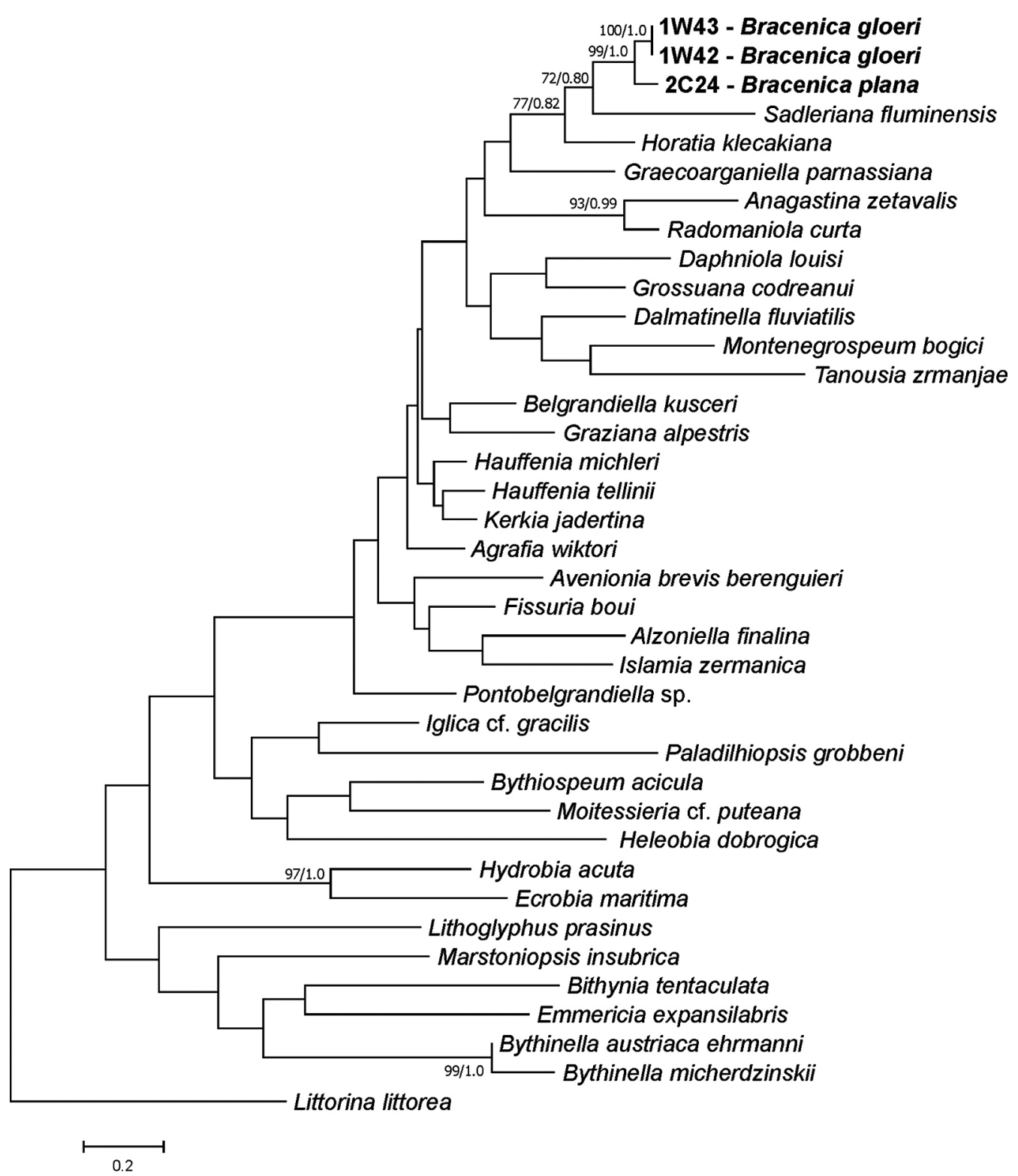

Fig. 4. Maximum likelihood tree based on mitochondrial COI. Bootstrap supports and Bayesian probabilities are given 


\section{TAXONOMIC PART}

\section{Superfamily Truncatelloidea Gray, 1840}

Family Hydrobiidae Stimpson, 1865

Subfamily Sadlerianinae Szarowska, 2006

Genus Bracenica Radoman, 1973

Type species: Bracenica spiridoni Radoman, 1973

Bracenica gloeri n. sp. Grego, Fehér et Erőss (Figs 5-12, 20-24)

Type locality. Montenegro, Kotor Bay, Herceg Novi, spring behind the car wash Nickević at crossing of E65 and Bratsva Jedistva Street $\left(42^{\circ} 27.72^{\prime} \mathrm{N}\right.$, $\left.18^{\circ} 31.21^{\prime} \mathrm{E}\right)$.

Type material. Holotype: Leg. ERÓsS Z. P. and FEHÉR Z. 21.07.2018, HNHM-MOLL 104161; Paratypes: same data, HNHM-MOLL 104162/120 wet; NHMUK 20190541/3 dry; SMF 356764/3 dry; NMBE 561366/3 dry; SBMNH 633040/3 dry; AMNH_IZC 00331522/2 dry; coll. Eróss/20 wet and 3 dry; coll. Grego/88 dry).

Etymology. Named after our friend, German malacologist Peter Glöer from Hetlingen, who extensively contributed to the study of the Balkan freshwater gastropod fauna.

Description. Shell (Figs 5-12) translucent with smooth and shiny surface and reddish horny periostracum, with three convex whorls, separated by a deep suture forming elevated spire. Shell valvatoid, slightly conical with a sub-circular, slightly tearshaped aperture and sharp peristome. Umbilicus widely open. In the holotype the aperture height to shell height ratio: 0.6 , height of body whorl to height of spire ratio: 4.6 , shell height $1.22 \mathrm{~mm}$, shell width $1.65 \mathrm{~mm}$. Operculum reddish-horny, circular, spiral, paucispiral; nucleus central in the form of characteristic, knob-like outgrowth (apophysis) on its inner side, spirally bent (Figs 20-22). The knobby structure spiral-wise elevated at its highest point. Body pigmentless, eyes absent. Female reproductive organs (Fig. 23) with big spherical bursa copulatrix and two seminal receptacles, the proximal one nearly vestigial, and the distal one big, sac-shaped. Penis (Fig. 24) with a characteristic outgrowth.

Measurements. Holotype: H $1.22 \mathrm{~mm}$; W 1.65 mm; BH 1.08 mm; BW 1.10 mm; AH 0.73 mm; AW $0.62 \mathrm{~mm}$.
Differentiating features. The shell of Bracenica gloeri n. sp. (Figs 5-9) differs in proportions from that of B. spiridoni (Fig. 19), also that figured by RADOMAN (1983: plate IV, fig. 58), as well as from the one of B. vitojaensis (Fig. 18), also that figured by GLÖER et al. (2015: figs 12-14): the body whorl is much higher, and the peristome is ovate, not circular. The bursa copulatrix is spherical, proportionally bigger than the ellipsoid one in B. spiridoni. The COI sequences-based phylogeny (Fig. 4) indicate Sadleriana fluminensis (Küster, 1853) as the sister clade of our Bracenica clade, close to Horatia klecakiana Bourguignat, 1887, within the subfamily Sadlerianinae Szarowska, 2006. B. gloeri and $B$. plana are sister taxa, with p-distance $=4.7 \%$.

Habitat. The live animals were found at the point of spring water outlet covered by a dense web of tree and bush roots. Live animals were found directly among the fine roots, or in the fine sandy sediment immediately below the root zone.

Distribution. Only known from the type locality.

\section{Bracenica plana (Bole, 1961) comb. nova}

Hauffenia plana Bole, 1961 (BOLE 1961)

(Figs 13-15)

Type locality. Ljuta pri Kotoru $=$ Spring Ljuta between Orahovac and Dobrota, $7 \mathrm{~km} \mathrm{~N}$ of Kotor $\left(42^{\circ} 29.14^{\prime} \mathrm{N}, 18^{\circ} 45.99^{\prime} \mathrm{E}\right)$. A seasonally very large spring emerging in a short gorge under limestone cliff of eastern Kotor Bay. In dry season the water is brackish; however, a few smaller freshwater outlets are permanently maintained throughout the year.

Remarks. The species was originally assigned to the genus Hauffenia; however, the molecular data of the topotype (whose morphology was in accordance with the description of BOLE 1961) refute its assignment to Hauffenia by SCHÜTT (2000) and HIRSCHFELDER (2017), and suggest its placement within the genus Bracenica. Unfortunately, there was no material fixed well enough for morphological study. The genetic differentiation between $B$. gloeri and B. plana described above is $4.7 \%$ (as opposed to $14.7 \%$ from Hauffenia), so they probably belong to Bracenica, not to Hauffenia. The valvatiform-shelled specimens from spring Ombla and from Popovo Polje were assigned to Hauffenia plana only based on the resemblance in shell morphology (SCHÜTT 2000, HIRSCHFELDER 2017). Considering the hydrological isolation of Ombla and Popovo Polje situated in Trebišnjica drainage basin from the Kotor Bay drainage area (STEVANOVIĆ et al. 2014) with the Ljuta spring and the type locality of our new species, it is highly unlikely that they would represent Bracenica plana. 

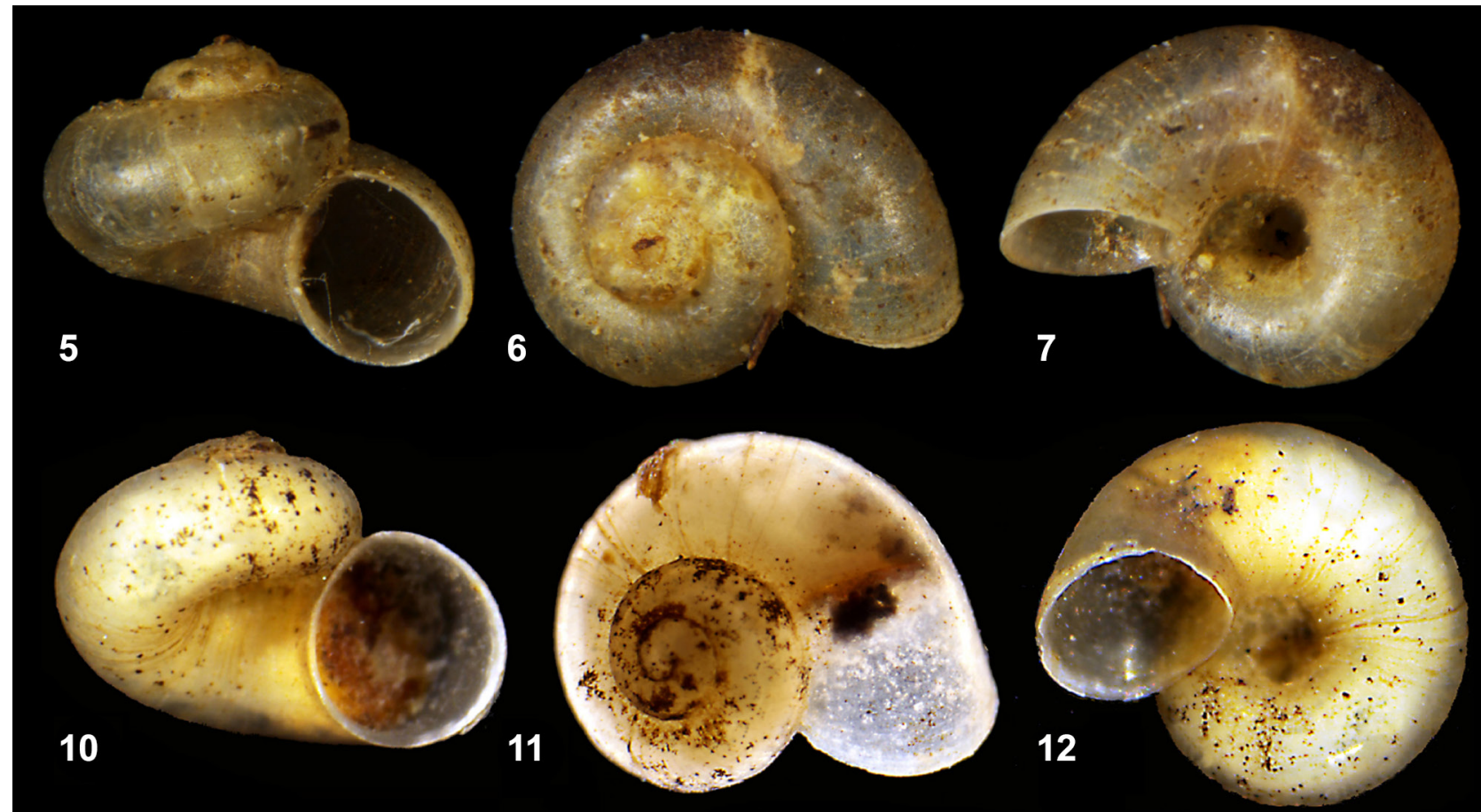

13

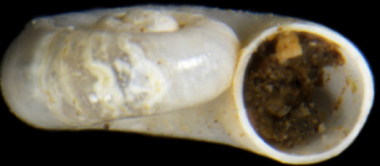

14
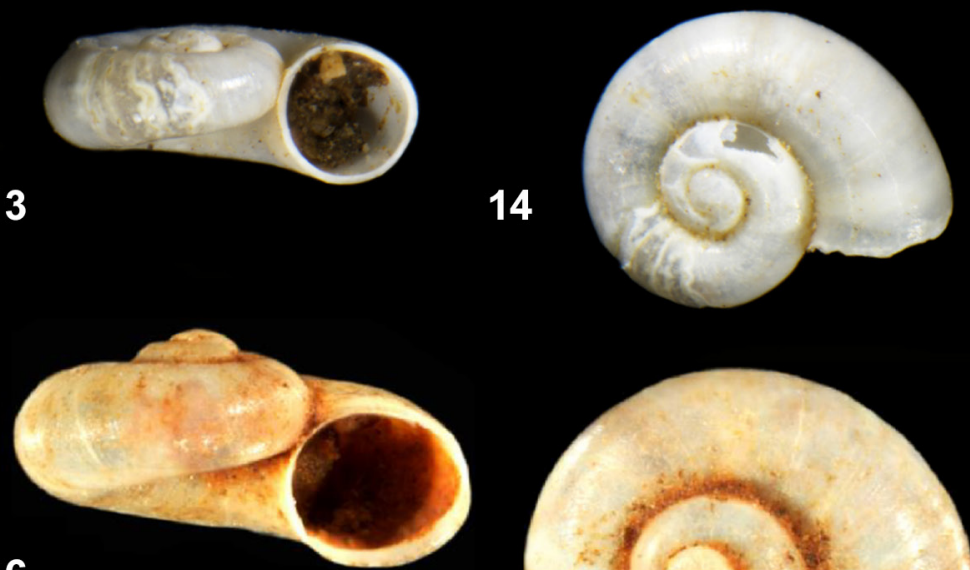

16
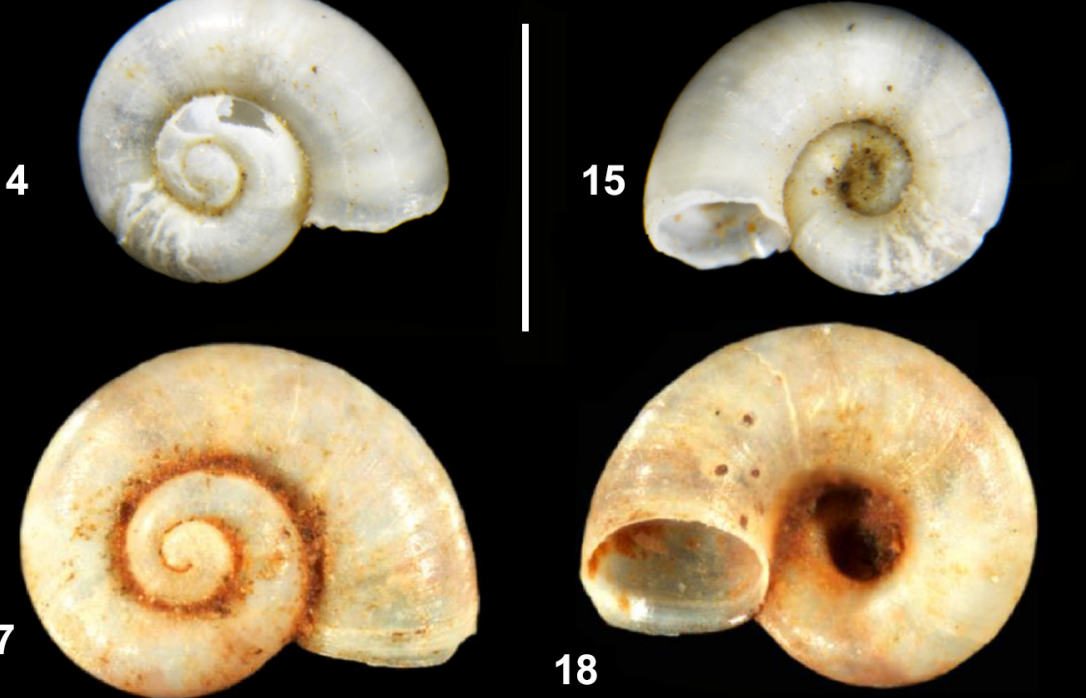

19
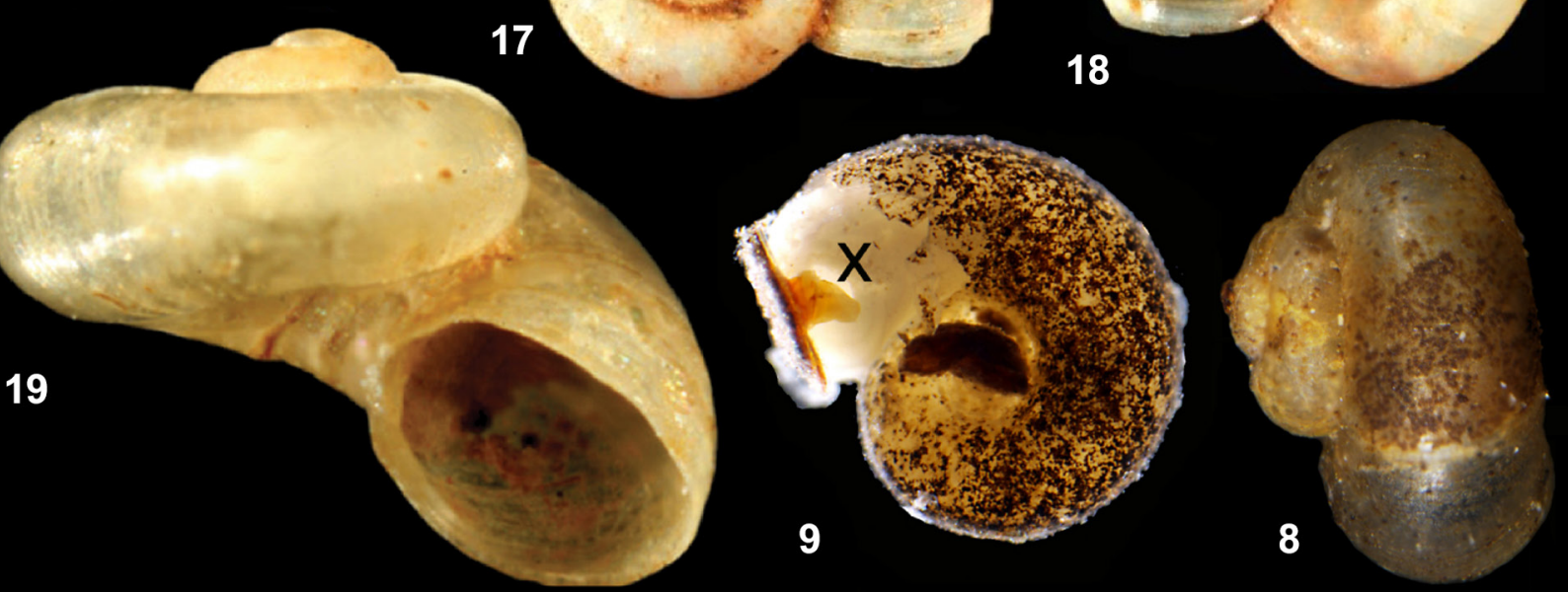

Figs 5-19. Bracenica species: 5-8 - holotype of Bracenica gloeri n. sp. HNHM-MOLL 104161, Montenegro, Kotor Bay, Herceg Novi; 9-12 - B. gloeri n. sp. live preserved specimens used for molecular and anatomical investigations, $\mathrm{X}$ indicates operculum peg; 13-15 - Bracenica plana (Bole, 1961), Kotor Bay, Spring Ljuta, topotype; 16-18 - paratype of B. vitojaensis Gloer, Grego, Erőss and Fehér, 2015, Montenegro, Podgorica, Spring Vitoja near Skadar Lake, coll. Grego; 19 - B. spiridoni Radoman, 1973, Montenegro, Karuč Spring. Scale bar $1 \mathrm{~mm}$ (Photo: A. RYSIEWSKA, P. GLÖER and J. GREGO) 

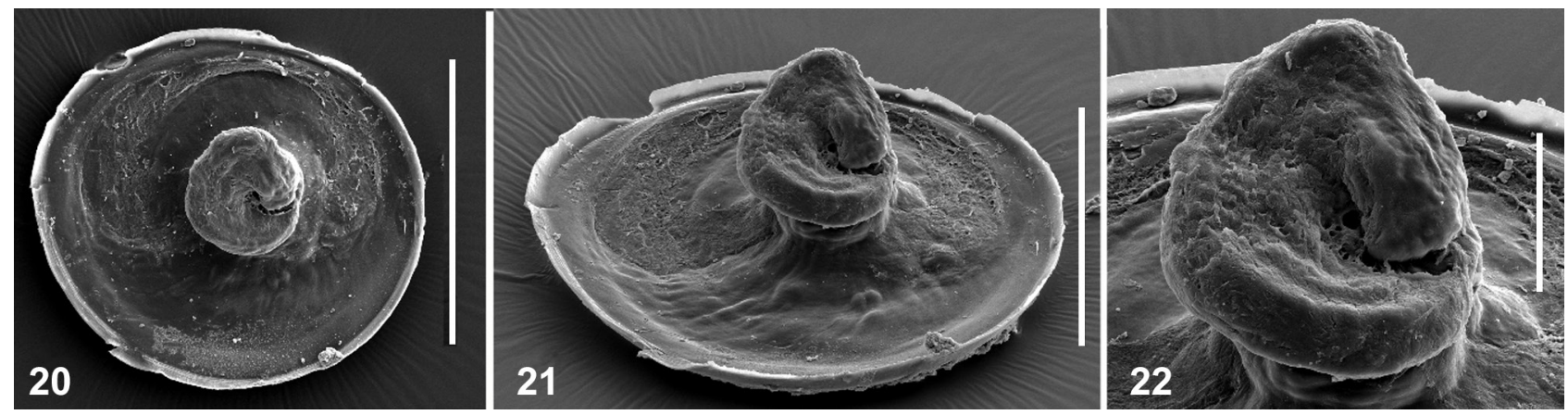

Figs 20-22. SEM photographs of the Bracenica gloeri n. sp. operculum. Scale bars $500 \mu \mathrm{m}$
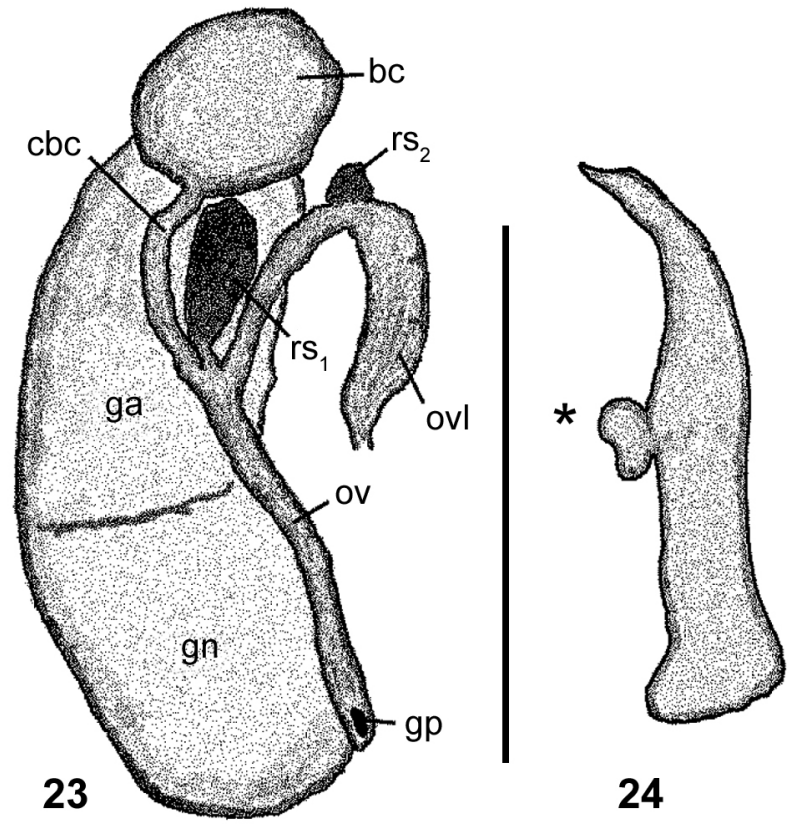

24
Figs 23-24. Reproductive organs of Bracenica gloeri n. sp.: 23 - renal and pallial section of female reproductive organs; 24 - penis (bc - bursa copulatrix, cbc - duct of bursa, ga - albuminoid gland, gn - nidamental gland, gp - gonoporus, ov - oviduct, ovl - loop of (renal) oviduct, $\mathrm{rs}_{1}$ - distal seminal receptacle, $\mathrm{rs}_{2}$ - proximal seminal receptacle; asterisk - outgrowth of the penis). Scale bar $500 \mu \mathrm{m}$

\section{DISCUSSION}

The operculum (Figs 9 and 20-22) with a characteristic outgrowth on its inner side was mentioned by RADOMAN (1983). The female reproductive organs (Fig. 23) are similar to the ones described and figured by RADOMAN (1983), in B. gloeri with a bigger, spherical bursa copulatrix and two seminal receptacles: proximal ( $\mathrm{rs}_{2}$ after RADOMAN 1973) small, nearly vestigial, and distal ( $\mathrm{rs}_{2}$ after RADOMAN 1973) very big, sac-shaped (Fig. 23), like in B. spiridoni. The penis (Fig. 24), long and slender, with a medium-sized outgrowth on its left side, is similar to the one described and drawn by RADOMAN (1983).

Many live animals of $B$. gloeri n. sp. were found directly among the fine roots, or in the sandy sediment just below the root zone. The find at this habitat confirmed our previous observations on valvatiformshelled gastropods living in similar habitats, associated with plant (tree and bush) roots. We observed identical associations also for the representatives of the genus Hauffenia Pollonera, 1899 from Slovakia and Hungary (H. kisdalmae Erőss et Petró, 2008), of the genus Kerkia Radoman, 1978 in north-western Bosnia, Daphniola Radoman, 1973 in Greece and Pontohoratia Vinarski, Palatov et Glöer, 2014 in Georgia. In all cases abundant populations were found in association with submerged fine roots. It is very likely that all five subterranean valvatiform-shelled genera prefer the shallow stygobiont habitat in the spring zone, where the water-saturated debris and gravel are within the zone of the fine plant roots, which are, in fact, the main source of organic matter in this subterranean habitat (CULVER \& PIPAN 2009, 2014). As all five genera share the similar valvatiform shell morphology, but, on the other hand, differ distinctly in both their anatomy and molecularly inferred phylogenetic position, it could be speculated that the root-associated habitat could support, as adaptation, such shell morphology. Further studies will be needed to 
understand the geographical distribution of Bracenica in the Dinaride Karst. The two genera, Bracenica and Hauffenia, are very distinct (p-distance $=0.157$ ), and probably belong to different genetic lineages (Fig. 4).

\section{REFERENCES}

BERAN L., HOFMAN S., FALNIOWSKI A. 2015. Tanousia zrmanjae (Brusina, 1866) (Caenogastropoda: Truncatelloidea: Hydrobiidae): a living fossil. Folia Malacologica 23: 263-271. https://doi.org/10.12657/folmal.023.022

BERAN L., OSIKOWSKI A., HOFMAN S., FALNIOWSKI A. 2016. Islamia zermanica (Radoman, 1973) (Caenogastropoda: Hydrobiidae): morphological and molecular distinctness. Folia Malacologica 24: 25-30. https://doi. org/10.12657/folmal.024.004

BOLE J. 1961. Nove Hydrobide (Gastropoda) iz podzemeljskih voda zahodnega Balkana. Biološski vestnik 9: 59-69.

Culver D. C., PiPAN T. 2009. The biology of caves and other subterranean habitats. Oxford University Press, Oxford UK.

Culver D. C., PIPAN T. 2014. Shallow subterranean habitats: ecology, evolution, and conservation. Oxford University Press, Oxford UK. https://doi.org/10.1093/ acprof:oso/9780199646173.001.0001

EDGAR R. C. 2004. MUSCLE: multiple sequence alignment with high accuracy and high throughput. Nucleic Acids Research 32: 1792-1797. https://doi.org/10.1093/nar/ gkh340

FALNIOWSKI A. 1990. Anatomical characters and SEM structure of radula and shell in the species-level taxonomy of freshwater prosobranchs (Mollusca: Gastropoda: Prosobranchia): a comparative usefulness study. Folia Malacologica 4: 53-142. https://doi.org/10.12657/folmal.004.005

FALNIOWSKI A., BERAN L. 2015. Belgrandiella A. J. Wagner, 1928 (Caenogastropoda: Truncatelloidea: Hydrobiidae): how many endemics? Folia Malacologica 23: 187-191. https://doi.org/10.12657/folmal.023.015

FALNIOWSKI A., SZAROWSKA M. 2011. A new genus and new species of valvatiform hydrobiid (Rissooidea; Caenogastropoda) from Greece. Molluscan Research 31: 189-199.

FALNIOWSKI A., SZAROWSKA M. 2012. Species distinctness of Lithoglyphus prasinus (Küster, 1852) (Rissooidea: Caenogastropoda). Folia Malacologica 20: 99-104. https://doi.org/10.2478/v10125-012-0019-x

FALNIOWSKI A., SZAROWSKA M. 2013. Phylogenetic relationships of Dalmatinella fluviatilis Radoman, 1973 (Caenogastropoda: Rissooidea). Folia Malacologica 21: 1-7. https://doi.org/10.12657/folmal.021.001

FALNIOWSKI A., WiLKE T. 2001. The genus Marstoniopsis (Rissooidea: Gastropoda): intra- and intergeneric phylogenetic relationships. Journal of Molluscan Studies 67: 483-488. https://doi.org/10.1093/mollus/67.4.483

FALNIOWSKI A., PEŠIĆ V., GLÖER P. 2014. Montenegrospeum Pešić et Glöer, 2013: a representative of Moitessieriidae?

\section{ACKNOWLEDGMENTS}

This study was supported by the National Science Centre under Grant 2017/25/B/NZ8/01372 to AF.

Folia Malacologica 22: 263-268. https://doi. org/10.12657/folmal.022.023

FALNIOWSKI A., SZAROWSKA M., GLÖER P., PEŠIĆ V. 2012a. Molecules vs morphology in the taxonomy of the Radomaniola/Grossuana group of Balkan Rissooidea (Mollusca: Caenogastropoda). Journal of Conchology 41: 19-36.

FALNIOWSKI A., SZAROWSKA M., GLÖER P., PEŠIĆ V., GEORGIEV D., HORSAK M., SIRBU I. 2012b. Radiation in Bythinella (Mollusca: Gastropoda: Rissooidea) in the Balkans. Folia Malacologica 20: 1-9. https://doi. org/10.2478/v10125-012-0006-2

FALNIOWSKI A., SZAROWSKA M., SIRBU I., HILlEBRAND A., BACIU M. 2008. Heleobia dobrogica (Grossu \& Negrea, 1989) (Gastropoda: Rissooidea: Cochliopidae) and the estimated time of its isolation in a continental analogue of hydrothermal vents. Molluscan Research 28: 165-170.

GlÖER P., Grego J., ERŐss Z. P., FehÉr Z. 2015. New records of subterranean and spring molluscs (Gastropoda: Hydrobiidae) from Montenegro and Albania with the description of five new species. Ecologica Montenegrina 4: 70-82.

Grego J., Hofman S., Mumladze L., FALNiOWsKi A. 2017. Agrafia Szarowska et Falniowski, 2011 (Caenogastropoda: Hydrobiidae) in the Caucasus. Folia Malacologica 25: 237-247. https://doi.org/10.12657/ folmal.025.025

HALl T. A. 1999. BioEdit: a user-friendly biological sequence alignment editor and analysis program for Windows 95/98/NT. Nucleic Acids Symposium Series 41: 95-98.

HERSHLER R., PONDER W. F. 1998. A review of morphological characters of hydrobioid snails. Smithsonian Contributions to Zoology 600: 1-55. https://doi. org/10.5479/si.00810282.600

HIRSCHFELDER H-J. 2017. Neue Molluskennachweise aus der Ombla-Quelle bei Dubrovnik. Mitteilungen der Deutschen Malakozoologischen Gesellschaft 96: 33-38.

HOFMAN S., RYSIEWSKA A., OSIKOWSKI A., GREGO J., SKET B., PREVORČNIK S., ZAGMAJSTER M., FALNIOWSKI A. 2018. Phylogenetic relationships of the Balkan Moitessieriidae (Caenogastropoda: Truncatelloidea). Zootaxa 4486 (3): 311-339. https://doi.org/10.11646/ zootaxa.4486.3.5

LAYTON K. K., MARTEl A. L., Hebert P. D. 2014. Patterns of DNA barcode variation in Canadian marine molluscs. PLoS ONE 9(4): e95003. https://doi.org/10.1371/ journal.pone.0095003

Miller M. A., Pfeiffer W., Schwartz T. 2010. Creating the CIPRES Science Gateway for inference of large phy- 
logenetic trees. Proceedings of the Gateway Computing Environments Workshop (GCE), 14 Nov., New Orleans, LA: 1-8. https://doi.org/10.1109/GCE.2010.5676129

Osikowski A., GeORGIEV D., Hofman S., FALNIOWSKI A. 2015. Does the genetic structure of spring snail Bythinella (Caenogastropoda, Truncatelloidea) in Bulgaria reflect geological history? ZooKeys 518: 6786. https://doi.org/10.3897/zookeys.518.10035

RADOMAN P. 1973. New classification of fresh and brackish water Prosobranchia from the Balkans and Asia Minor. Posebna Izdanja Prirodnjackego Muzeia, Beograd 32: $1-30$.

RADOMAN P. 1983. Hydrobioidea a superfamily of Prosobranchia (Gastropoda). I. Systematics. Serbian Academy of Sciences and Arts, Monograph 547, Department of Sciences 57: 1-256.

RAMBAUT A. 2010. FigTree v1.3.1. < http://tree.bio.ed.ac. uk/software/figtree>.

RAmbaut A., DRUMmond A. J. 2009. Tracer v1.5. < http:// beast.bio.ed.ac.uk/Tracer>.

RiCHLING I., MALKOWSKY Y., KUHN Y., NiEDERHÖFER H.-J., BOETERS H. D. 2016. A vanishing hotspot - impact of molecular insights on the diversity of Central European Bythiospeum Bourguignat, 1882 (Mollusca: Gastropoda: Truncatelloidea). Organisms Diversity \& Evolution 17: 67-85. https://doi.org/10.1007/s13127-016-0298-y

RONQUIST F., TESLENKO M., VAN DER MARK P., AYRES D.L., DARLiNG A., HÖHNA S., LARGET B., LiU L., SUCHARD M. A., HuELSENBECK J. P. 2012. Mr.Bayes 3.2: efficient Bayesian phylogenetic inference and model choice across a large model space. Systematic Biology 61: 539 542. https://doi.org/10.1093/sysbio/sys029

RysiewSKA A., GeORgIEV D., OSIKOWSKi A., HofMAN S., FALNIOWSKI A. 2016. Pontobelgrandiella Radoman, 1973 (Caenogastropoda: Hydrobiidae): A recent invader of subterranean waters? Journal of Conchology 42: 193203.

RYSIEWSKA A., PREVORČNIK S., OSIKOWSKI A., HOFMAN S., BERAN L., FALNIOWSKI A. 2017. Phylogenetic relationships in Kerkia and introgression between Hauffenia and Kerkia (Caenogastropoda: Hydrobiidae). Journal of Zoological Systematics and Evolutionary Research 55: 106-117. https://doi.org/10.1111/jzs.12159

SCHÜTT H. 2000. Die Hohlenmollusken der Omblaquelle (The Subterranean Mollusca of Ombla Spring). Natura Croatica 9: 203-215.

STAMATAKIS A. 2014. RAxML Version 8: a tool for phylogenetic analysis and post-analysis of large phylogenies. Bioinformatics 30: 1312-1313. https://doi. org/10.1093/bioinformatics/btu033

Stevanović Z., PeKaš Ž., Jolović B., PAMBukU A., RADOJEVIĆ D. 2014. Classical dinaric karst aquifer - an overview of its past and future. In: KUKURIĆ N., STEVANOVIĆ Z., KREŠIĆ N. (eds). The Proceedings conference Karst Without Boundaries, Trebinje: 23-28.

SZAROWSKA M. 2006. Molecular phylogeny, systematics and morphological character evolution in the Balkan Rissooidea (Caenogastropoda). Folia Malacologica 14: 99-168. https://doi.org/10.12657/folmal.014.014
SZAROWSKA M., FALNIOWSKI A. 2011. An unusual, flagellum-bearing hydrobiid snail (Gastropoda: Rissooidea: Hydrobiidae) from Greece, with descriptions of a new genus and a new species. Journal of Natural History 45: 2231-2246. https://doi.org/10.1080/00222933.20 11.591067

SZAROWSKA M., FALNIOWSKI A. 2013a. Phylogenetic relationships of the Emmericiidae (Caenogastropoda: Rissooidea). Folia Malacologica 21: 67-72. https://doi. org/10.12657/folmal.021.007

SZAROWSKA M., FALNIOWSKI A. 2013b. Species distinctness of Sadleriana robici (Clessin, 1890) (Gastropoda: Rissooidea). Folia Malacologica 21: 127-133. https:// doi.org/10.12657/folmal.021.016

SZAROWSKA M., FALNIOWSKI A. 2014a. Horatia Bourguignat, 1887: is this genus really phylogenetically very close to Radomaniola Szarowska, 2006 (Caenogastropoda: Truncatelloidea)? Folia Malacologica 22: 31-39. https:// doi.org/10.12657/folmal.022.003

SZAROWSKA M., FALNIOWSKI A. 2014b. Ventrosia mariti$m a$ (Milaschewitsh, 1916) and $V$. ventrosa (Montagu, 1803) in Greece: molecular data as a source of information about species ranges within the Hydrobiinae (Caenogastropoda: Truncatelloidea). Folia Malacologica 22: 61-67. https://doi.org/10.12657/folmal.022.006

SZAROWSKA M., GRZMIL P., FALNIOWSKI A., SIRBU I. 2007. Grossuana codreanui (Grossu, 1946) and the phylogenetic relationships of the East Balkan genus Grossuana (Radoman, 1973) (Gastropoda: Rissooidea). Hydrobiologia 579: 379-391. https://doi.org/10.1007/ s10750-006-0530-4

SZAROWSKA M., HOFMAN S., OSIKOWSKI A., FALNIOWSKI A. 2014. Daphniola Radoman, 1973 (Caenogastropoda: Truncatelloidea) at east Aegean islands. Folia Malacologica 22: 269-275. https://doi.org/10.12657/ folmal.022.021

SZAROWSKA M., OSIKOWSKI A., HOFMAN S., FALNIOWSKI A. 2016. Pseudamnicola Paulucci, 1878 (Caenogastropoda: Truncatelloidea) from the Aegean Islands: a long or short story? Organisms Diversity \& Evolution 16: 121139. https://doi.org/10.1007/s13127-015-0235-5

Tamura K., Peterson D., Peterson N., Stecher G., Nei M., KUMAR S. 2013. MEGA5: Molecular evolutionary genetics analysis using maximum likelihood, evolutionary distance, and maximum parsimony method. Molecular Biology and Evolution 28: 2731-2739. https://doi.org/10.1093/molbev/msr121

Wilke T., DAVIS G. M., FALNIOWSKI A., GIUSTI F., BODON M., SZAROWSKA M. 2001. Molecular systematics of Hydrobiidae (Mollusca: Gastropoda: Rissooidea): testing monophyly and phylogenetic relationships. Proceedings of the Academy of Natural Sciences of Philadelphia 151: 1-21. https:// doi.org/10.1635/0097-3157(2001)151 [0001:MSOHMG]2.0.CO;2

Wilke T., RolÁN E., DAVIS G. M. 2000. The mudsnail genus Hydrobia s.s. in the northern Atlantic and western Mediterranean: a phylogenetic hypothesis. Marine Biology 137: 827-833. https://doi.org/10.1007/ s002270000407 
XIA X. 2000. Data analysis in molecular biology and evolution. Kluwer Academic Publishers, Boston, Dordrecht \& London.

XIA X. 2013. DAMBE: A comprehensive software package for data analysis in molecular biology and evolution. Molecular Biology and Evolution 30: 1720-1728. https://doi.org/10.1093/molbev/mst064
Xia X., Xie Z., Salemi M., Chen L., Wang Y. 2003. An index of substitution saturation and its application. Molecular Phylogenetics and Evolution 26: 1-7. https:// doi.org/10.1016/S1055-7903(02)00326-3

Received: November 26th, 2019

Revised: April 15th, 2020

Accepted: April 16th, 2020

Published on-line: May 16th, 2020 